\title{
Parameters of the Transition from a Cultural to a Political Program by the Czech and Slovak Elites in the Mid-19th Century
}

\author{
Vratislav Doubek
}

Masaryk Institute and Archives of the Czech Academy of Sciences

\begin{abstract}
This article examines the rise of the nascent intellectual and business bourgeois elites of the Czechs and Slovaks, focusing on the transformation of their cultural program into a political one. The article takes a comparative approach and investigates the relationship of political programs to prepolitical identities, zooming in on the parameters of a broader Czech and Slovak state identity, including the role of the center (Vienna, Pest, Prague, or Pressburg) or language (analyzing both its unifying and divisive roles in bridging the ideas and visions of the emerging local elites). As I argue, in the case of the Czech and Slovak nationalist movements, we can observe a transition from a prepolitical to the political program in the mid-19th century itself.
\end{abstract}

\section{Keywords}

prepolitical program; political program; nation; nationalism; political elites; Czech; Slovak

\section{Introduction}

Aside from looking at political history, any examination of the politicization of bourgeois elites needs to pay particular attention to the history of ideas and political thought too. Looking at it from a Central European perspective, this approach has a strong tradition, especially in Poland and Hungary, partly also in Slovakia, but not in the Czech lands. This is yet another reason why we need to build on analytical works within political theory (e.g., works of the Slovak philosopher Tibor Pichler) ${ }^{1}$ or works that are so broadly conceived that they include similar approaches (e.g., works of the Czech social historian Jiřr Štaif). ${ }^{2}$ The recent volume coedited by the Hungarian historian Balázs Trencsényi represents an important

\footnotetext{
* Vratislav Doubek, Masaryk Institute and Archives of the Czech Academy of Sciences, Gabčíkova 2362/10, Prague 182 00, Czech Republic; vdoubek@post.cz

1 See especially Pichler Tibor, Etnos a polis. Zo slovenského a uhorského politického myslenia, Bratislava 2011; Pichler, Národovci a občania. O slovenskom politickom mysleni v 19. storočí, Bratislava 1998.

2 See, among other works, Štaif Jiří, Obezřetná elita. Česká společnost mezi tradicí a revolucí 1830-1851, Praha 2005.
} 
contribution to this discussion. ${ }^{3}$ Taking these works as a point of departure, in what follows, I examine the processes of politicization in the Czech and Slovak contexts in the first half of the 19th century.

The cultural and economic rise of the nascent intellectual and business bourgeois elites from the late 18th century was complemented by what were initially unconscious endeavors to make their mark in the political arena. As time went by, this ambition was nurtured and accomplished as an independent factor. These processes were commensurable in Central Europe. Moreover, even in the case of a delay of their individual phases, acceleration and partial alignment occurred in the revolutionary period at the turn of the 1840s. To meet an eligibility criterion for determining the transition between a culturally politicizing ambition and manifestation of a specific political interest, it is necessary to perceive the efforts to formulate and configure concretely achievable programs. The pressing nature or extent of the demands was, in this context, not as important as their feasibility, the viability of the intention. Hence, in what follows, I examine the transition from the culturally politicizing stage to the political stage of the maturing bourgeois elites as the precondition of the creation of realistic and feasible programs considering the example of Czech-Slovak nationalizing intellectuals.

\section{Pan-Slavism Versus Political Realism}

From the perspective of the budding Czech political elites, a classic example that is usually mentioned of the shift from romantic cultural-politicizing to realistic political considerations is the changing attitude to the Pan-Slavic question. When the Czech journalist Karel Havlíček Borovský advanced in 1846, as a declaration of war, the simple thesis that the Slavs are not one nation but consist of a number of separate and distinct peoples - even if with opposing interests - this notion was not the fruit of far-sightedness and timelessness, but one of political realism. It was proof of the maturity of not only Havlíček himself, but of his generation, prepared to put forward new demands. Havlíček was speaking in the name of a generation that was already faced with the challenge of political work and political considerations. And this challenge led it to seek, ask questions, and work toward viable solutions. In this respect, Pan-Slavism was an irrational project, which on the political level must have been perceived by the previous generation. But because the latter had not been confronted with such a challenge, it was not forced to voice this conclusion aloud and did not have to admit it; it suppressed it,

3 Trencsényi Balázs, Janowski Maciej et al., A History of Modern Political Thought in East Central Europe, Vol. 1: Negotiating Modernity in the "Long Nineteenth Century", Oxford 2017. 
ignored it, and toyed with apolitical concepts, which, with some disdain and underestimation, are referred to as merely cultural or, at the most, cultural and politicizing.

Earlier prepolitical debates, out of a lack of confidence in own ambitions, focused on a union of all the Slavs around the strongest and free (because independent) Russia. They were not public debates but private ones, which showed only a willingness for political considerations, but for the time being, no readiness to face up to the consequences. We find in them, however, elements that had the makings of political considerations, based on an intersection between general (national) interest and constitutional ideas. Searching for the interconnectedness between the national and constitutional interests at the time was hampered not only by natural inexperience but also by a lack of clarity of the terms. The transition from undefined, and therefore often speculative, considerations to clearly defined concepts and theses created confusion and tension even between individual streams and groups of the same interest. It was necessary to put more precisely both the concept of the nation and its constitutional anchoring and identity.

As the external constitutional framework seemed to be established, it was generally shared. The Czech political program forged its broader state identity by the mid-19th century in the Habsburg monarchy. It identified itself with the latter and sought its development within it. But that was just a part of the constitutional concept. In the interest of a comprehensive political ambition, it was necessary to build up and promote the argumentation to clarify the internal ties and internal identity that would link the national community and the territory it administers. In order to develop this inner, narrower constitutional identity of the nation, it was necessary to exercise the authority of the center of political action in respect of the lands that were perceived as Czech. In addition to the generally acknowledged superior empire center (Vienna), the idea of a lower-level authority, a semicentric entity, was being mooted. This position of a national semicenter was claimed by Prague. It was important for the prepolitical debate to determine which of the countries and regions of Prague would play the role of the administrative semicenter, which also related to the perception of the dispersion of the nation and its densely populated areas.

Prague was perceived - historically, traditionally, and naturally - as the center of the former Kingdom of Bohemia. The strategy for the future course of action in exerting the authority of the administrative center of the country was most naturally pursued in other parts of the Crown Lands of Bohemia. Although this historically established and organic whole was formally separated in its 
administration, it was incontestably homogeneous in language. It comprised Moravia and residual Silesia, which, after the wars of the past, still remained part of the Habsburg Empire. These lands were perceived as constituents of the provincial administrative and national nucleus. But, at the time when a realistic political agenda was drawn up and Prague harbored the ambition to become the administrative center of all these lands, its ambition proved problematic.

In the early months of the revolutionary events of spring 1848, two delegations with lists of Czech political demands were sent to the Vienna Imperial Court. Both lists included a demand for administrative unification of the Crown Lands of Bohemia and the establishment of a common provincial government headquartered in Prague. ${ }^{4}$ In other words, this meant unification of the administration of Bohemia and Moravia in the Prague center. The same point was included in the wording of the Czech program of the Havlíček newspaper: "Whoever opposes a union between Bohemia and Moravia, we consider a traitor to the nation and our sworn enemy. It is only this union that can lead to the common good and glory of the Bohemian and Moravian people." Similarly, Moravian newspapers carried popular articles on the necessity of a reinforced Czech-Moravian unity. They were signed by a friend of Havlíček, namely, Alois Šembera. ${ }^{6}$ But the response of the Moravian political representation was prompt and, on the contrary, very negative.

The Vienna Government called on the Moravian Provincial Assembly to comment on the Czech political ambitions. In its reply of 14 April, ${ }^{7}$ what was then the Estates' Assembly, and which later became an elected Assembly, rejected these considerations roundly in its draft Constitution of 20 September. ${ }^{8}$

The Moravian Province had only one level, administrative, not linguistic and national. In this respect, it was even more problematic to apply the authority of the Czech political elites to the sub-Carpathian regions of Upper Hungary, i.e., Slovakia, which - later, in 1918 - actually laid, together with the Czech

4 První petice Pražská, 11. Března 1848 - Druhá petice Pražská, 29. března 1848, reprint in: Černý Jan M. (ed.): Boj za právo I-II. Sborník aktů politických u vécech státu a národa českého od roku 1848 s výklady historickými, Praha 1893 (reprint 2007), here Part I: Až do rozpuštění sněmu Kroměřížského (11. Března 1848 - 7. Března 1849), pp. 31-45, 106-113.

5 Ibid.

6 Reinfeld Barbara K., Karel Havlíček (1821-1856). A National liberation leader of the Czech Renascence, New York 1982, p. 35.

7 Stavovský sněm moravský proti spojení s Čechami, 14. dubna 1848, in: Černý Jan M. (ed.): Boj za právo I, Part D, pp. 207-213.

8 Tobolka Zdeněk, Politické dějiny československého národa od r. 1848 až do dnešní doby, Part I: 18481959, Praha 1932, pp. 69-70. 
Lands, the foundation for a common Czech-Slovak state. The ambition for a constitutional unity could not rely on the historical tradition of joint administration, and the interpretation of Slovak as merely a dialectically different form of the Czech language met with resistance in Slovakia.

The period Czech discourse was well aware of the controversial nature of the issue. It was as if it took for granted the existence of a Czech nation and the lands colonized by it in Upper Hungary but did not find enough courage to transmute this thesis into a political demand. Therefore, in the late 1840s, when the up-and-coming Czech political elite revealed its program for a united administration, we find in it practically no comments on the status of Slovakia. For the moment, Slovakia remained outside the program scope of Czech politics, which tried to keep the Slovak question as a certain preparatory model and a side issue, which would only be tackled after having addressed the basic aspects of cementing the status of the kernel.

At this level, we can observe the relation to Slovakia in the long term, from the years of the prepolitical debates. A brochure by the Czech publicist Jakub Malý in 1845 advanced an argument for a constructive Czech pro-Austria attitude for fear that after a breakup of the Hapsburg monarchy, Slovakia would move away from the Czech Lands without return.'

\section{The National Languages of the Czech-Slovak Relationship}

The lack of authority to push for a consistent state-based concept could not be made good even by evidence of cultural and linguistic proximity. From the beginnings of romantic nationalism, a common language was perceived as the identifying mark of a unified national community. The entire emerging generation of the active propounders of the Czech National Revival, including the linguist Josef Jungmann, was working to raise the consciousness of the linguistic national bonds as a proof of the community's viability and power. Language-based nationalism seemed to be an ideal complement to the dynamically evolving ideology of the newly emerging bourgeois elites, namely, liberalism, as it did not question the universal values of individual human freedom and reciprocity. ${ }^{10}$ It could elaborate on them and transform them into claims of the national wholes, but it did not contradict them. The

9 [Malý Jakub], Worte eines Čechen veranlasst durch die GrafJ. M. Thun'sche Broschüre Der Slavismus in Böhmen, Leipzig 1845. ["Die österreichischen Slawen wissen sehr gut, dass mit dem Untergange Oesterreichs Zersplitterung ihr Loos sein würde; die Čechen allein würden durch eine Trennung der Krone Böhmens vom übrigen Oesterreich politisch abgesondert werden von 3 Millionen ungarischen Stammgenossen, die sich derselben Schriftsprache mit ihnen bedienen." See Ibid, pp. 17-18.]

10 For comparative development of this prepolitical phase at the center, see Trencsényi, Janowski et al., A History of Modern Political Thought in East Central Europe, p. $191 \mathrm{nn}$. 
boundaries between the identities of one language circuit and the other were blurred and, in the cultural sense, they did not seem to compete. Thus, the initial illusory concept of nationalism was broadened as a tool for positive integration of the individual ethnic groups, which does not complicate, and which facilitates, the process of general fraternization.

The combination of idealistic notions integrating language and constitutional identity was maturing in its speculative, yet politicized, form, leading to conclusions on a cultural and linguistic Pan-Slav unification: "In 100 or more years, Europe is going to change profoundly, and the change will be coming from Russia, I believe fervently. I firmly believe that the Russian power will outlast the Frankish one, and this must be gratifying to us, the Slavs, when all the Slavonic dialects become one language. We will receive language learning from the Russians, the Russians will accept it from us. Thus, what we write in Czech, we write for that great empire of the Slavs. From my heart, I would like to disseminate this idea through the newspaper but it is not yet the right moment."11

In the politics-shaping process, this generalized tribal nationalism was maturing in the notion of the nation and its standard common language. At the same time, the politicization added to the concept of nationalism an element of negative definition of one nation against another one, or national rivalry. Although language nationalism produced the illusion of unity, it did not guarantee it. The problem of the prepolitical phase of nationalism was that it was barely aware of the competition between the national groups, which only became apparent at the time of the formulation of concrete national political interests and programs. Nor did it realize the internal friability of national identity, once again visible in the context of the progressive maturing of the individual groups (cultural, ethnic, religious, and - ultimately - also political) within the national community. Advocates of a positive national integrity always allowed the claim for national self-determination on the basis of the widest sustainable ethnic union. A bond that proved or was to prove a sufficient degree of cultural coexistence was declared to be definitely terminated, and further self-identification efforts were now mercilessly stigmatized for being seditious and subversive.

As a consequence, the situation was more complicated in Slovakia. If the Czech representatives did not understand the self-governing ambitions of a linguistically unified Moravia, they were equally at a loss to recognize the efforts of the "Hungarian Czechs" to reject the unifying role of the Czech

11 Letter from J. Jungmann to A. Mark of February 9, 1810, cited according to Jungmann Josef: Boj o obrozeni národa. Selected Works. Arranged by Felix Vodička. Prague: F. Kosek, 1948, p. 147. 
language, and, on the contrary, to lay down the principles of their own literary language. Czech had indeed had its tradition in Slovakia in the cultural and religious milieu. Slovak Protestants used a translation of the Kralice Bible from the 16th century, and the Czech scriptural language became a natural linguistic means for them. But, the new Slovak elites rejected this possibility of bridging the lack of linguistic identity.

\section{Slovak Cultural Prepolitical Program and Štúr's Optimism}

Likewise, the Slovak cultural prepolitical program took a self-sacrificing assimilative approach. It responded both to the possibilities and the real ambitions of a weak cultural awareness and to the contemporaneous ideals of fraternization common to all humankind. Under the influence of linguist and translator Josef Jungmann (1773-1847), the Czech cultural elite called for a struggle for the rescue and development of Czech, anticipating in the same breath its being sacrificed in favor of a common, superior interest in Pan-Slav cultural growth.

Similarly, Slovak revivalists promised concessions from the principles of the Slovak language construction in the form of diminishing vocalization. ${ }^{12}$ They perceived this as a prerequisite for a prospective linguistic convergence with Czech. Over time, both sides were confronted with another less-selfless approach on the part of their potential partners. As a result, a need for differentiation arose. This process was often regarded not only as legitimate and natural, but also as continual. "We have long been antagonistic towards the Czechs," wrote Slovak publicist Jozef Miloslav Hurban in late 1842, "We are Slovaks through and through, there is nothing Czech in us, our works are fruit of the true spirit of the Slovaks, why do not the Czechs recognize us?"' ${ }^{2}$ At a time when the Slovak bourgeois elite had come to declare linguistic autonomy on its way to a cultural and political stabilization, this move necessarily led to a sharp disagreement in Bohemia as it undermined Prague's unifying cultural and political ambition as the center of the Czech national movement.

The reflection of the Czech self-determination, however, remained positive only in its integrative ambition, and it caused negative reverberations not only in the conflict with the external pressures from other national groups, but also in recognizing the internal inconsistency and attempting

12 Letters from L. Štúr to K. B. Štorch and F. Palacký, reprint in: Jozef Ambruš (ed.), Listy Ludovíta Štúra, part I: 1834-1843, Bratislava 1954, p. 90, 94.

13 Letter from Hurban to Škultéty of December 27, 1842, quoted according to Novotný Ján, O bratrské družbě Čechů a Slováků za national obrození, Prague 1959, pp. 184-185. 
to extend the self-determination to other parts of the supposedly unified national commonwealth. Therefore, when a group of three Slovak cultural representatives, Ludovít Štúr, Michal M. Hodža, and Jozef M. Hurban, decided in July 1843 to declare a new status of the Slovak language and, in the following years, published the first texts written in this language, these steps ran into stiff resistance in the Czech milieu. The departure from Czech was a step in a cultural-linguistic struggle, and it undoubtedly carried political signals. It was typical that its instigators had consciously sought to make it a political one. The act of separation was proclaimed "law", in the form of a memorandum and "implementing regulations", which were laid down in Štúr's pamphlet of 1846, Nárečja slovenskuo alebo potřeba pisaňja v tomto nárečí.

The very first book text printed by Hurban according to this standard, Nitra Almanach, published in $1844,{ }^{14}$ did not generate much excitement in Prague. Only Štúr's pleading and explanation of the approach 2 years later ${ }^{15}$ ran into resistance from the Czech intellectual circles. The very intent was provocative as was its reasoning context. "The Czechs are a tribe distinct from ours; their history is not ours as we have had no participation in it." ${ }^{\prime 16}$ When Štúr differentiated from the Czechs not only the Slovaks but also stressed the dissimilarity of the Moravians, "who still help them a little [i.e., the Czechs]" ${ }^{\prime 17}$ and the actual small family of the Czechs, this was indigestible for the Czech elites' concept. The Museum Committee for Czech Language and Literature published, in the year 1846, an anthology of Czech and Slovak authors who were speaking and had spoken in favor of a common language. ${ }^{18}$ The anthology contained 33 votes in support of a common Czech-Slovak language and conjectures of self-destructive consequences of the Slovak language autonomism, as we read in the writings of the historian František Palacký: “... those immature and inexperienced men have taken a path that will lead them and their followers directly to rack and ruin." ${ }^{\prime 19}$ Havlíček then popularized the anthology on the pages of his newspaper, adding his opinion to the foregoing. ${ }^{20}$

\footnotetext{
14 Hurban Miloslav Jozef (ed.), Nitra, Vol. 2, Bratislava 1844.

15 Štúr Ludevít, Nárečja slovenskuo alebo potřeba pisaňja v tomto nárečí, Prešpork 1846.

16 Ibid, p. 81.

17 Ibid, p. 83.

18 Hlasowé o potřebě jednoty spisowného jazyka pro Čechy, Morawany a Slowáky, Prague 1846.

19 Ibid, p. 31.

20 Havlíček Borovský Karel, Hlasové o potřebě ... (Pražské noviny, May 10, 1846 and May 14, 1846), reprint in: Ibid, Politické spisy I: Pražské noviny, Prague 1900, pp. 103-118.
} 
The Czech mission of integration with Slovakia had limited options in the field of linguistic and cultural unification. Through language separation, the Slovak elite rejected the integration efforts of the Czechs. At the same time, however, it refused to accept the basic paradigms of constitutional unity, not only with respect to the Czech core and Prague as the provincial administration center, but also its relationship with Vienna, and the definition of the term superior center was also problematic. To them, the traditional center of the Hungarian administration was Pest (or Budapest, after 1873), and the approach favoring Vienna, which we can also observe at this time, was part of a purposeful, essentially escapist politico-constitutional strategy. After all, the proclamation of the Slovak language identity had not been inspired only by the desire to differentiate itself from the Czech one, but it was also a reaction to a further wave of introduction of Hungarian as a new official language of the land after Latin. The mounting Magyarization pressure led the Slovak elites to reconsider the constitutional reasoning in their approach to Hungary and Pest.

The attempts to follow the autonomous procedure with regard to the Hungarian administration led to an emphasis on the imperial authority symbolized by Vienna and the Vienna Government. A supplication from Slovak Protestants organized by Ján Čaplovič in 1842 revealed a greater leaning on the superior empire center. It appealed to the ruler expediently as the supreme secular representative of the Protestant Church to plead for protection against the manifestations of Magyarization and the authority of the Hungarian Provincial Assembly. ${ }^{21}$ Further documents from that period show an increased emphasis on the authority of the Vienna Court. Štúr followed this up and referred to it in his anonymously published letter of complaint when he wrote, "... one who is being maltreated begs the authorities to restore peace. The abused petitioner does not trouble anyone but the offender... We did not turn to any foreign government, so we are not to blame when we appealed to our government that stands above all of us." ${ }^{22}$ Here, too, he asserted in the name of the Slovaks the common provincial Hungarian identity, and to preserve the nation's rights and dignity, he appealed to the superior imperial authority. It is important to realize the basic political potential of these relations, the fact that this was "the first time the Slovaks had voiced a potentially political, rather than a purely cultural, form of nationalism.. ${ }^{23}$ The ultimate manifestation of

21 Slovenský prestolný prosbopis (Vienna, June 6, 1842), in: Dokumenty slovenskej národnej identity a státnosti I, Bratislava 1998, pp. 294-297.

22 [Štúr Ludovít], Žaloby a ponosy Slovákov v Uhorsku na protizákonné prechmaty Madarov, Lipsko 1843 , p. 45.

23 Brock Peter, The Slovak National Awakening, p. 42. 
this strategy was a document based on the Austrian, and more particularly the Hungarian Revolution of 1848-1849, which allowed for the secessionist claim to Hungary of March 19, $1849 .^{24}$

It cannot be therefore said that the departure of the Slovak conception from the Czechs (and Bohemia) strengthened its Hungarian bond. The efforts to enhance the perception of Vienna as the metropolis, a strong center, must have had a secondary impact, undermining the authority of Pest as the administrative center. Naturally enough, for the Hungarian elites, this exposition was unacceptable, if not treasonable, but from the Slovak perspective, it was quite natural. It was essentially a balancing of authority, an effort to confirm the provincial Hungarian identity, putting up barriers against the overdominant and exacting influence of the Magyar-Hungarian political administration.

Preoccupied by its own interests, Prague was misinterpreting these moves. It perceived any resistance to its own integration role as favoring Hungary, and vice versa, and it understood undermining the authority of Pest as its gain. On the Czech side, the crushing of the Hungarian uprising in August 1849 and the subsequent Vienna Government's restrictive pressure against the Hungarian elites were welcomed with great enthusiasm. This was not only in the interest of the "Hungarian Czechs", but also with a view to achieving their own universal ambitions. The hope that negotiations would be held over the future of these territories in a tense situation brought a conciliatory tone to an otherwise-sharp disagreement with the Slovak linguistic separation. ${ }^{25}$ Havlíček welcomed the publication of the official Slovak newspaper with a fervent hope for a future change. "The language in which the main political section [...] is written in pure Slovak, in which we do not notice, as before, in Štúr's newspaper, an odious departure from Czech, but rather its approaching... Lo and behold! the right path that will eventually lead to unity of the whole Czechoslovak tribe in a single written language: The hope on which we base the whole future of our nation, Bohemia, Moravia and Slovakia, a nation of seven million people, which will never be as small as any other, as if the three of us had to take separate roads [...]" ${ }^{\text {"26 }}$ It was no accident

24 Pamätný spis slovenskej deputácie, predostrený Františkovi Jozefovi I. v Olomouci 19. marca 1849, reprint in: Bokes František (ed.), Dokumenty k slovenskému národnému hnutiu v rokoch 1848-1914, Part 1: 1848-1867, Bratislava 1962, pp. 62-63. [German original reprinted in Rapant Daniel, Slovenské povstanie ... I-III, retrieved]

25 Šamberger Zdeněk, Karel Havlíček a austroslavismus po Slovanském sjezdu 1848, in: Slovanské historické studie, Vol. 22, Praha 1996, pp. 5-41, here especially 17 foll.

26 Havlíček Borovský Karel, Slovenské noviny (Národní noviny, 11. 8. 1849), reprint in: Ibid, Politické spisy II: Národní noviny (1848-1850), Part 2, Prague 1902, pp. 639-640. 
that the weakening of the Hungarian power position caused the Czechs to declare an open Czech-Slovak interest.

These ambitions were based on flawed assumptions, however. In fact, the Štúr group never accepted the Czech political point of view concerning the CzechSlovak union as a planned federalization of the empire. In the enthusiasm of the revolutionary era, the Slovak representation expressed itself with respect to the hopeful Hungarian and Austrian identities, but not the Czechoslovak one. Slovak writer Viliam Paulíny-Tóth called, as late as 1845 , for a strong and just Hungarian government: "Now the Hungarian land is equally our homeland, and with gratitude shall we live and sacrifice our lives for her." ${ }^{27}$ But when the developments led to the defeat of the Hungarian uprising and hence wielding of Vienna's authority, the secessionist demands were incessant, in favor of relinquishing the Hungarian identity and embracing the Slovak pro-Austrian vision. ${ }^{28}$

Nonetheless, we do not see a turn toward the strengthened authority of Prague, as a peripheral center at least, not even at the time of the most significant Czech activities. During the Slavonic Congress in Prague in June 1848, Hurban formulated, in the Czech-Slovak section, some fundamental requirements of political nature, defining them in the interest of the Slovak and Ruthenian nation. ${ }^{29}$ Indeed, this association between the Slovak and Ruthenian interests was the first known association of this kind, although it represented the provincial and not the ethnic reality of the kindred interests. The Slovaks and the Ruthenians wanted to be heard in their interest, in which they felt united. The Slovak cultural and political elites avoided a clear constitutional definition of this interest, especially in the initial stages, emphasizing work for the land and the homeland. In revised formulations, these interests were linked to different protectionist conceptions - Austrian and Hungarian, for which they sought a power base in Pest, alternatively in Vienna, with a secondary provincial center in Pressburg (today Bratislava), but not in Prague.

27 Cited according to Tibenský Ján, Slovensko I. Dějiny, Bratislava 1978, p. 501.

28 See Pamätný spis slovenskej deputácie, predostrený Františkovi Jozefovi I. v Olomouci 19. marca 1849, reprint in: Bokes František (ed.), Dokumenty $k$ slovenskému národnému hnutiu v rokoch 1848-1914, Part 1: 1848-1867, Bratislava 1962, pp. 62-63. [German original reprinted in Rapant Daniel, Slovenské povstanie ... I-III, retrieved].

29 Cf. Manifest Slovanského sjezdu k evropským národům z 12. června 1848, reprint in: Čapka František (ed.), Dokumenty a materiály ke studiu národnich dějin v letech 1848-1918, Brno 2010, pp. $14-16$. 


\section{Slavs and the World of the Future}

Concerning Štúr, the situation became critical in the 1850s after the end of the revolutionary era. At that time, he wrote an essay entitled Das Slawenthum und die Welt der Zukunft, in which he challenged an elaborate conception, according to which the Slovaks sought allies and variants of balanced authorities and supports. He denied the importance and the role of the hitherto-recognized power base, Vienna and the Hapsburgs, and established a new center of authority that he transferred eastward. This change of strategy was buttressed by a host of arguments. However, it should be noted that this was done outside of the wider debate, because Štúr's text in question had not yet been published. But this does not alter the nature of this new variant of constitutional thinking in Slovakia.

Denouncing Austria, Štúr called it a constituent part of an excessively liberalized order that compromised the traditional value of authority. Although he did not view the Vienna Court as being liberal, the power system in the empire seemed to him to be too much under the influence of newly emerging forces that clamored for a weakening of the established order. If, in the 1840s, favoring Vienna under pressure from Pest meant the ideological context of favoring Metternich conservatism over Kossuth liberalism, then loss of the Hungarian and Austrian imperial identities resulted from the disappointment over the revolution and the upheaval that the Vienna Court was unable to prevent. In this sense, Štúr also opposed and questioned the Czech and Hungarian liberal nationalists as followers of a fashionable, materialistic, liberal trend, which in his eyes questioned the authority and the confidence in the order and thereby opened the door to odious revolution and communism. In addition, the Czechs represented to him a somewhat-embarrassing imitation of the German-European power interest. In contrast to this dissipated Europe, the author insisted on originality, respect for authority, and the order of Russia and the Eastern Slavs. Fostering mistrust toward the goals of liberalism and their actual or supposed European bearers, Štúr retreated to increasingly conservative positions, seeking originality, naturalness, and authority, whose influence would bring an end to the unwanted dissemination of political, religious, and ethical liberalism. ${ }^{30}$

30 Cf. Borodovčák Viktor, Austroslavismus a hungarofilstvo v období martinského shromaždenia roku 1861, in: Slovanský prehled, 1987, Vol. 63, No. 2, pp. 109-117. ["In politischer Beziehung stürzt der Westen aus absoluten Monarchien in konstitutionelle Staaten, aus diesen wieder in politische und zuletzt in sociale und communistische Republiken, wo dann Alles mit Auflösung der Menschheit und Vernichtung jeder Meschlichkeit endet. ... Da ist kein Halt und keine Ruhe, hier will alles vorwärts, hier drängt alles, hier pocht alles, hier erblickt alles das endliche, ersehnte Glück - im Verderben! Revolutionen auf Revolutionen werden da folgen und nach einer jeden, werden die Völker des Westens schlechter daran sein, als früher. ... Sucht also das von Menschlenliebe entflammte Herz die Hilfe im Westen vergeblich, wohin ist der Blick zu wenden, wo Hoffnung zu schöpfen? Dort im weiten Osten, denn dort liegt das Slawenvolk ausgebreitet, das Volk der Zukunft!" Štúr L'udovít, Das Slawenthum und die Welt der Zukunft, Bratislava 1931, pp. 132-133]. 
Štúr's interpretation was not only an elliptical transition from one constitutional concept, Austrian or Hungarian, to another one, Pan-Slavic, Pan-Russian, by a simple change of the center of authority (Vienna and Pest for Saint Petersburg and Moscow). By this stage of development, there was an equally important shift to a different way of reasoning, noted by scholar Szabó, who observed that, "This requirement is legitimated by the Orthodox political theology. Štúr does not want to regenerate the West by reason, but by Eastern Christianity, in which 'the cult occupies the same position as the doctrine'. It is a perceptive insight but it is possible and necessary to elaborate it. Štúr was not concerned 'only' with the application of the dichotomy of intellect-cult, but, in general, with the transition from constitutional concepts to ideal concepts. Štúr does not deny that the harbor which Slovakia should enter in the future in order for the Slovaks to find the freedom for their natural development is Russia. But his reasoning is idealistic, it is not a Russia of strong statehood, army, the Tsarist family, it is an ideal of naturalness, purity, originality, tradition; it is a symbol of positive values that Štúr sees in Russia. Only in these mounting arguments did the author arrive at a definitive conclusion: Since Russia is the bearer of these ideal values, it is also the bearer of autonomy, power and world power, with the prospect of becoming a real political leader and protector. However, in regard of the reasoning, this was merely a conclusion rather than a point of departure."31

\section{Conclusion}

I began this essay with a claim that the criterion for the transition from the culturally politicizing stage to the political stage of the maturing bourgeois elites was the creation of realistic and feasible programs. Stúr's progress in Slovakia seems to question this, and we can extend this challenge even to the Czech conditions. At the beginning of the 1860s, Austria returned to the model of a constitutional monarchy, and the Czech deputies returned to the benches of the Imperial Diet. Czech political thought exercised the option of political work and reflection now, though the conditions for the assumption of its own integration role were far from optimal at this time. Further developments not only overrode but also reversed them. The disappointment over the inability to achieve their political ends and the fear of enacting a nightmare scenario after the defeat in the Austro-Prussian war in 1866 and after the dualist division of the Hapsburg Empire also led the Czech politicians to politically unfeasible, if not irrational, considerations.

31 Szabó Miloslav, Národ a rod v Štúrovom politickom myslení, in Chmel Rudolf (red.), L'udovít Štúr. Štúdie a eseje, Bratislava 2015, pp. 184-191, here p. 189. 
During the war, a single plan couched in separatist terms for the restoration of an independent Czech Kingdom was published. ${ }^{32}$ In the late 1860s, leading Czech politicians worked to put into action the "Konstantin Plan" to annex the Czech Lands to an envisioned Pan-Slav empire ruled by the Russian Tsar. ${ }^{33}$ Czech politicians did not openly espouse political Pan-Slavism, but it remained in its consciousness as a pressure relief valve for a time of a real or supposed crisis. It was taken up again by Karel Kramář, the future prime minister of the Czechoslovak Republic, who wrote a confidential draft of the Constitution of the Pan-Slavic Empire just before the outbreak of the First World War. ${ }^{34}$

Does this mean that the entire starting thesis on seeking viable programs as evidence of engagement in politics was called into question? It does not as this criterion can be applied in full just to the initial phase of the transformation of the cultural elites into a political representation. In the future, it was already deformed, and realistic or idealistic approaches were pursued as needed according to the current situation. The political representations of the 1850 s and 1860s were the same as those who, with optimism, experienced the opening of the political space in the 1840s. Their work in the public space was already standardized; it was a day-to-day reality. Jungmann did not receive any calls for political work (and reflections) and therefore addressed the context of the questions on a cultural level, avoiding political debates and political considerations. Now, the situation of Štúr, Hurban, Palacký, and the others was different. They were tied to a specific historical reality that anticipated their considerations. In the watershed years, the determinant factor for society's mental development was not the euphoria from the accelerated phase of development going by leaps and bounds, but the disappointment with the underestimation of the development alternatives. In a phase where the possibility of free political work, and hence political thinking, was reversed and questioned, not only the starting point but the overall approach to the problem changed. The new elites no longer had the necessity to seek a solution with realistic political parameters and switched to idealistic categories. Yet, this does not mean they ceased to think politically. Only for their continued political thought did they feel the need to seek and find appropriate tools for political work, or to rely on the feasibility parameters at their disposal.

32 [Kotík Antonín], Pláč Koruny české, Berlin 1866.

33 Konstantinův plán, see Doubek Vratislav, Česká politika a Rusko (1848-1914), Praha 2004, p. $123 \mathrm{nn}$; in 1914, this vision would be embraced again by a leading Czech politician, Karel Kramár.

34 Kramář Karel, Ústava slovanské říše, in: Paulová Milada (ed.), Dějiny Maffe. Odboj Čechi̊ a Jihoslovanů za světové války 1914-1918, Part II: Annexes, Prague 1939, pp. 635-640. 
Thus, the transition from a realistic to an idealistic program should not be viewed as a return to the past or a loss of political sense as such. In the cultural struggle, the preceding generation, as stated earlier, was not forced to seek a realistic strategy as it was faced with the exigency of political work, and for this reason, it toyed with apolitical conceptions. In the 1850s, the rise of neoabsolutism barred the formerly politically active elites from political work. And, there was no way back. This generation had already entered the public space, had had its experience, and could not abandon its political ambitions. Its juggling with unrealistic conceptions had different parameters: it was a result of helplessness and uncertainty, a conscious escape from political realism, which did not offer enough options for advancing this preceding generation's interests and visions.

\section{References}

Bokes, František (ed.). Dokumenty k slovenskému národnému hnutiu v rokoch 1848-1914, Part 1: 1848-1867. Bratislava 1962.

Borodovčák, Viktor. Austroslavismus a hungarofilstvo v období martinského shromaždenia roku 1861, in: Slovanský prehled, 1987, Vol. 63, No. 2, pp. 109-117.

Brock, Peter. The Slovak National Awakening. An Essay in the Intellectual History of East Central Europe. Toronto 1976.

Čapka, František (ed.). Dokumenty a materiály ke studiu národnich dějin v letech 1848-1918. Brno 2010.

Černý, Jan M. (ed.). Boj za právo I-II. Sbornik aktů politických u věcech státu a národa českého od roku 1848 s výklady historickými. Praha 1893 (reprint 2007).

Dokumenty slovenskej národnej identity a štátnosti I. Bratislava 1998.

Doubek, Vratislav. Česká politika a Rusko (1848-1914). Praha 2004.

Havlíček, Borovský Karel. Politické spisy I. Prague 1900 . Politické spisy II. Prague 1902.

Hlasowé o potřebè jednoty spisowného jazyka pro Čechy, Morawany a Slowáky. Prague 1846.

Hurban, Miloslav Jozef (ed.). Nitra. Vol. 2. Bratislava 1844.

Jungmann, Josef. Boj o obrození národa. Selected Works. Arranged by Felix Vodička. Prague: F. Kosek, 1948.

Kotík, Antonín. Pláč Koruny české. Berlin 1866.

Kramář Karel, Ústava slovanské říše, in: Paulová Milada (ed.), Dějiny Maffie. Odboj Čechů a Jihoslovanů za světové války 1914 - 1918, Part II: Annexes, Prague 1939, pp. 635-640.

Malý, Jakub. Worte eines Čechen veranlasst durch die GrafJ. M. Thun'sche Broschüre Der Slavismus in Böhmen. Leipzig 1845.

Novotný, Ján. O bratrské družbě Čechů a Slováků za national obrození. Prague 1959.

Pichler Tibor. Etnos a polis. Zo slovenského a uhorského politického myslenia. Bratislava 2011. 


\section{Vratislav Doubek, Transition from a Cultural to a Political Program}

1998.

Tibenský, Ján. Slovensko I. Déjiny. Bratislava 1978.

Tobolka, Zdeněk. Politické dějiny československého národa od r. 1848 až do dnešni doby, Part I: 1848-1959. Praha 1932.

Trencsényi, Balázs, Janowski Maciej et al. A History of Modern Political Thought in East Central Europe, Vol. 1: Negotiating Modernity in the "Long Nineteenth Century." Oxford 2017.

Reinfeld, Barbara K., Karel Havlíček (1821-1856). A National liberation leader of the Czech Renascence. New York 1982.

Šamberger, Zdeněk. Karel Havlíček a austroslavismus po Slovanském sjezdu 1848, in: Slovanské historické studie, Vol. 22, Praha 1996, pp. 5-41.

Štaif, Jiří. Obezřetná elita. Česká společnost mezi tradicí a revoluci 1830-1851. Praha 2005.

Štúr, Ludovít. Das Slawenthum und die Welt der Zukunft. Bratislava 1931.

Štúr Ludevít. Nárečja slovenskuo alebo potřeba pisaňja v tomto náreči. Prešpork 1846.

Štúr, Ludovít. Žaloby a ponosy Slovákov v Uhorsku na protizákonné prechmaty Mad'arov. Lipsko 1843.

Szabó, Miloslav. Národ a rod v Štúrovom politickom myslení, in Chmel Rudolf (ed.), Ludovit Štúr. Štúdie a eseje. Bratislava 2015, pp. 184-191. 